\title{
Effect of suction on volume change and shear behaviour of an overconsolidated unsaturated silty soil
}

\author{
A.R. Estabragh ${ }^{* 1}$ and A.A. Javadi ${ }^{2}$ \\ ${ }^{1}$ Assistant Professor in Geotechnical Engineering, Faculty of Soil and Water Engineering, \\ University of Tehran, PO BOX 4411 Karaj 31587-77871, Iran \\ ${ }^{2}$ Computational Geomechanics Group, College of Engineering, Mathematics and Physical Sciences, \\ University of Exeter, Devon, EX4 4QF, UK
}

(Received April 27, 2011, Revised December 14, 2011, Accepted January 10, 2012)

\begin{abstract}
This paper presents the results of an experimental study on the effect of suction on compressibility and shear behaviour of unsaturated silty soil under various types of loading. A series of laboratory experiments were conducted in a double-walled triaxial cell on samples of a compacted silty soil. In the experiments the soil samples were subjected to isotropic consolidation followed by unloading and subsequent reloading under constant suction and prescribed overconsolidated ratio. The experimental results are presented in the context of an elasto-plastic model for unsaturated soil. The effects of suction on mechanical behaviour of unsaturated silty soil are presented and discussed. It is shown that increasing suction affects the shear behaviour of unsaturated soils, but there is a limit beyond which, further increase in suction will not result in any significant change in the behaviour.
\end{abstract}

Keywords: unsaturated soil; suction; overconsolidation ratio; triaxial cell.

\section{Introduction}

Unsaturated soil is a three phase material containing soil particles, water and air. The mechanical behaviour of unsaturated soil is strongly influenced by both pore air pressure $\left(u_{a}\right)$ and pore water pressure $\left(u_{w}\right)$. The difference between $u_{a}$ and $u_{w}$ is defined as suction $\left(s=u_{a}-u_{w}\right)$.

Early investigations of the mechanical behaviour of unsaturated soils focused on attempts to combine total stress, $\sigma$, pore air pressure, $u_{a}$ and pore water pressure, $u_{w}$ within a single effective stress, $\sigma^{\prime}$ as suggested by Bishop (1959)

$$
\sigma^{\prime}=\sigma-u_{a}+\chi\left(u_{a}-u_{w}\right)
$$

where $\chi$ is a factor varying with the degree of saturation, $S_{r}$, from zero for dry soil to unity for fully saturated conditions. Jenning and Burland (1962) were the first authors to challenge with the validity of Bishop's effective stress. They suggested that the mechanical behaviour of an unsaturated soil can not be described in term of a single stress state parameter because the suction within the pore

\footnotetext{
*Corresponding author, Assistant Professor, E-mail: raeesi@ut.ac.ir
} 
water and external stress applied to the boundary of a soil element act in qualitatively different ways on the soil skeleton. Therefore it led to use of two stress state variables: net stress $\left(\sigma-u_{a}\right)$ and suction $(s)$.

One of the applications of the concept of two independent stress state variables is to explain the volume change behaviour of unsaturated soil. Matyas and Radhakrishna (1968) were amongst the first researchers to consider the two stress state variables as two independent stress states for describing the volume change of unsaturated soil. Fredlund and Morgenstern (1977) proposed sets of constitutive equations to relate the volume change of unsaturated soil to two stress state variables. Another important contribution of two stress state variables is the development of a constitutive model for unsaturated soil behaviour by Fredlund et al. (1978) who suggested a relationship between the shear strength of unsaturated soil and two stress state variables as:

$$
\tau=c^{\prime}+\left(\sigma-u_{a}\right) \tan \phi^{\prime}+\left(u_{a}-u_{w}\right) \tan \phi^{b}
$$

where $c^{\prime}$ and $\phi^{\prime}$ are the cohesion intercept and friction angle (with respect to effective stress) at saturation condition and $\phi^{b}$ is the angle of internal friction with respect to suction. Fredlund et al. (1987) treated $\phi^{b}$ as constant for a particular soil. However, it subsequently became apparent that $\phi^{b}$ can not be a constant, because when suction increases to very high values the soil can not have infinite value of shear strength, which means that $\phi^{b}$ should decrease with increasing suction (Escario and Saez 1986 and Gan et al. 1988). In fact the value of $\phi^{b}$ would be equal to $\phi^{\prime}$ until suction reaches the air entry value of the soil, which is sufficient for pore air to start entering the soil. After this transition from saturated to unsaturated state, the tangent value of $\phi^{b}$ would keep on decreasing to a value much lower than that of $\phi^{\prime}$ as the suction increases.

Some other researchers such as Karube (1988), Bolzen et al. (1996), Kohgo et al. (1993) and Khalili and Khabbaz (1998) proposed alternative stress state variables for their constitutive models, in such a way that a single stress state variable can exclusively represent the variation of shear strength. Lu and Likos (2004 and 2006) also highlighted the nonlinear behaviour in the relationship between shear strength and matric suction and pointed out that this nonlinearity is a significant factor in limiting the general validity of the extended Mohr-Coulomb failure criterion for unsaturated soils. They indicated an alternative failure criterion which makes use of Bishop's effective stress concept and also includes a material variable termed capillary cohesion.

In recent years researchers have been attempting to analyse unsaturated soil behaviour in terms of constitutive relations linking volume change; shear deformation and strength in a single elastoplastic model. Alonso et al. (1987) were among the first researchers to propose an integrated framework incorporating both the volumetric and shear behaviour of unsaturated soil. This proposed framework was based on the theory of elasto-plasticity and was initially proposed in qualitative way, rather than with full mathematical development. A fully developed mathematical formulation for unsaturated soil was proposed by Alonso et al. (1990) in the form of a critical state type model. This model is now widely known as the Barcelona Basic Model (BBM). Wheeler et al. (2003) and Gallipoli et al. (2003) concluded from experimental results that the degree of saturation has a significant influence on stress-strain behaviour of an unsaturated soil. They employed a stress variable that takes into account the degree of saturation in addition to any influence of suction and proposed a new elasto-plastic model for unsaturated soil that involved coupling of hydraulic hystersis and mechanical behaviour. Other researchers such as Russell and Khalili (2006) and Khalili et al. (2005) proposed bounding surface plasticity models for mechanical behaviour of saturated soils. Bounding surface plasticity modelling of mechanical behaviour has recently been extended to unsaturated soil 
by researchers such as Datcheva and Schanz (2003), Russel and Khalili (2006) and Yang et al. (2008).

Rahardjo et al. (2004) performed a number of shear tests on unsaturated soil samples to simulate the stress paths followed by soil elements in a slope that fails under drained and undrained conditions. Review of the literature reveals that this has not been studied for overconsolidated soils and the effects of suction and overconsolidation ratio on the shear behaviour of unsaturated soils have not been thoroughly investigated. Therefore, this study focuses on the effect of suction and overconsolidation ratio on the consolidation and drained shear behaviour of unsaturated silty soil. The experimental program and results are presented and discussed below.

\section{Testing procedures}

A series of suction controlled consolidation and triaxial tests were carried out on samples of compacted silty soil to investigate the influence of suction on mechanical behaviour of unsaturated soil. The silty soil used in this work consisted of 5\% sand, $90 \%$ silt and $5 \%$ clay. It had a liquid limit of $29 \%$ and plasticity index of $19 \%$. All samples were prepared at a water content of $10 \%$ (4\% below the optimum value from the standard proctor compaction test). Static compaction was carried out in nine layers, each layer being compacted at the rate of $1.5 \mathrm{~mm} / \mathrm{min}$ to a maximum vertical stress of $1600 \mathrm{kPa}$, The dimensions of the samples were $38 \mathrm{~mm}$ diameter and $76 \mathrm{~mm}$ height. The surface between each two layers, was scarified to ensure good contact with layers. The samples compacted in this condition were uniform and repeatable. Therefore, static compaction was found to be more reliable than the other methods. This method of preparing sample also was used successfully by other researchers such as Sivakumar (1993) and Sharma (1998).

The tests on unsaturated soil samples were done in a Bishop-Wesley hydraulic triaxial cell, modified to a double-walled cell (Estabragh et al. 2004). Before the main tests, calibration tests were carried out in order to estimate the volume change of different components of the system (including water absorption by the acrylic cell walls, apparent volume change of the cell due to the effects of cell pressure, loading ram displacement and drainage line) and to make the necessary corrections to the measurements. The suction in the samples was controlled by the axis translation technique. The samples were initially subjected to an equalization stage with a prescribed set of mean net stress and suction imposed on the sample. During equalization period (varying from 7 to 10 days depending on the value of suction imposed) the sample reached equalization at a specified stress state. Subsequently all samples were subjected to isotropic consolidation to a defined mean net stress. The next stage involved isotropic unloading to a predefined value of mean net stress and the final step was shearing (reloading). Isotropic loading, unloading and reloading were carried out at constant suction.

The soil water characteristic curve was established in the double wall triaxil cell under mean net stress of $50 \mathrm{kPa}$. An initial suction of $50 \mathrm{kPa}$ was created in the sample by using $u_{a}$ and $u_{w}$ equal to 350 and $300 \mathrm{kPa}$ respectively. Then the pore air pressure was kept constant and the $u_{w}$ was decreased to $50 \mathrm{kPa}$ at the rate $0.8 \mathrm{kPa} /$ hour. Therefore, the final suction created in the sample was $300 \mathrm{kPa}$.

\section{Test results}

In consolidation test the mean net stress was increased from 20 or $50 \mathrm{kPa}$ to $550 \mathrm{kPa}$ (target 


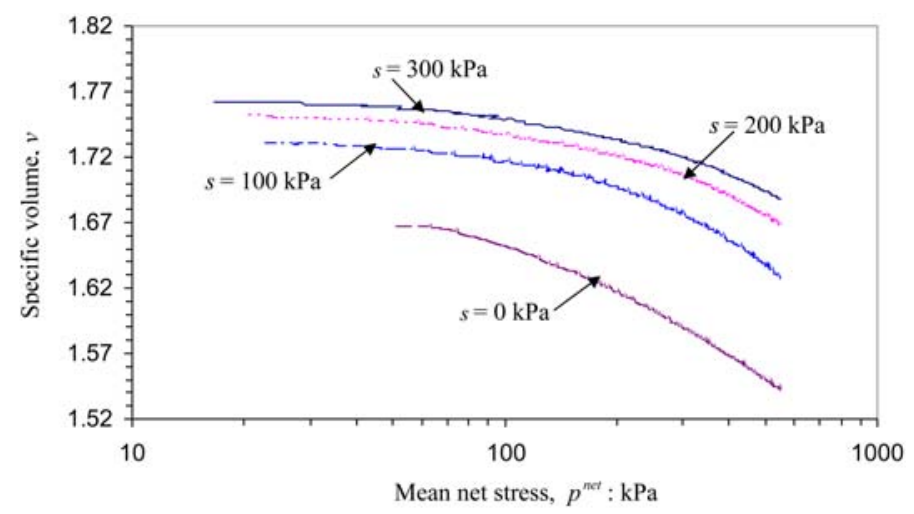

Fig. 1 Variation of specific volume during consolidation for different values of suction

value) while holding the suction constant $(0,100,200$ or $300 \mathrm{kPa})$. Typical variation of specific volume $(v)$ with mean net stress $\left(p^{\text {net }}\right)$ during consolidation is shown in Fig. 1. It is shown in this figure that the volume of the soil sample decreased as the mean net stress increased. A continuous increase in mean net stress caused the soil to start to yield at some point. The value of yield stress was estimated by the method of intersection of two linear segments of the consolidation curve as suggested by Cui and Delage (1996). As expected, the yield value increased with increasing suction. Therefore, when the yield stress at a particular value of suction was exceeded, the soil state fell on an isotropic normal consolidation line. The values of the slope $(\lambda(s))$ and intercept $(N(s))$ of normal consolidation lines were calculated from the results in Fig. 1. The variations of $\lambda(s)$ and $N(s)$ with suction are shown in Figs. 2 and 3.

Shearing was performed at the end of unloading stage, when final isotropic confining pressure was held constant. Drained shear tests were conducted at constant cell pressure and under constant suction. In this work five cell pressures, 50, 100, 200, 300 and $400 \mathrm{kPa}$ (corresponding to OCR values $11,5.5,2.75,1.83$ and 1.37) and four values of suction, $0,100,200$ and $300 \mathrm{kPa}$ were used. During the tests the variations specific volume and water content were recorded. Typical results of the triaxial tests for $s=100 \mathrm{kPa}$ are shown in Fig. 4. Compression of a sample during shearing is

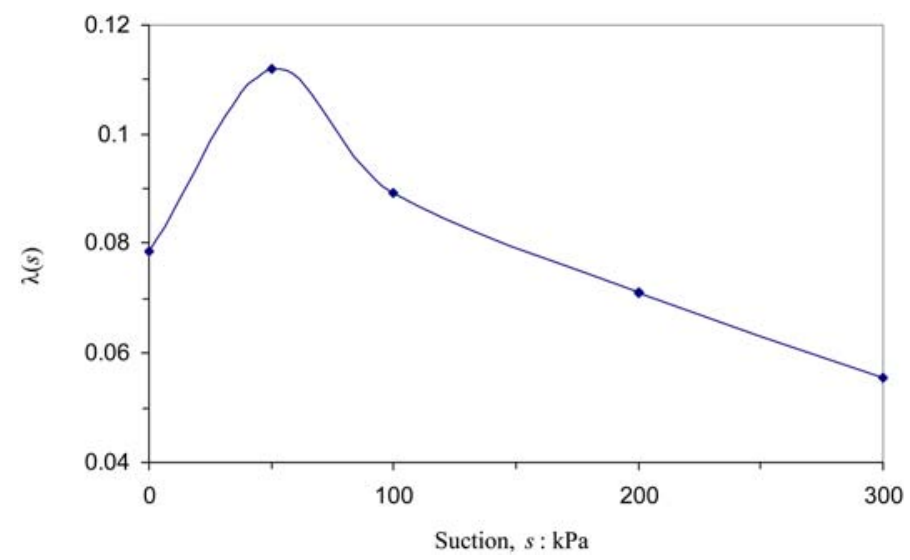

Fig. 2 Variation of $\lambda(s)$ with suction 


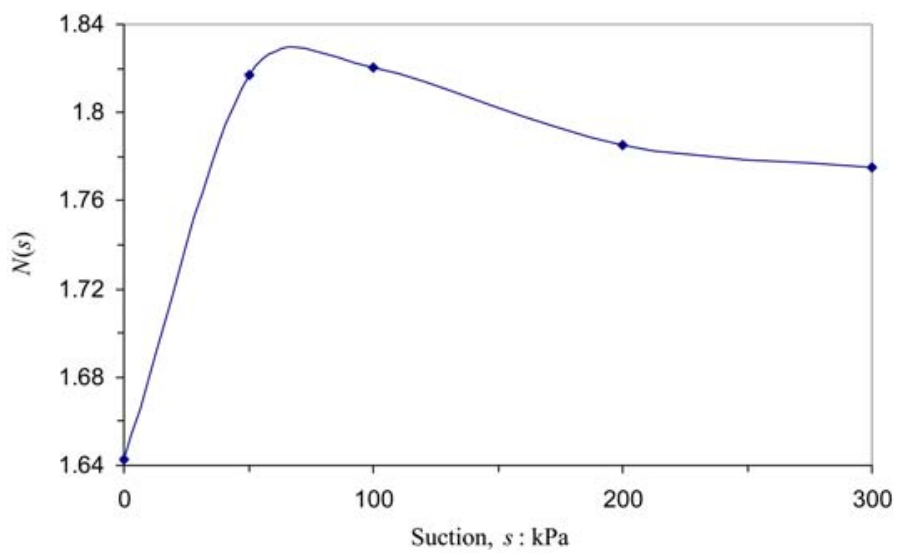

Fig. 3 Variation of $N(s)$ with suction

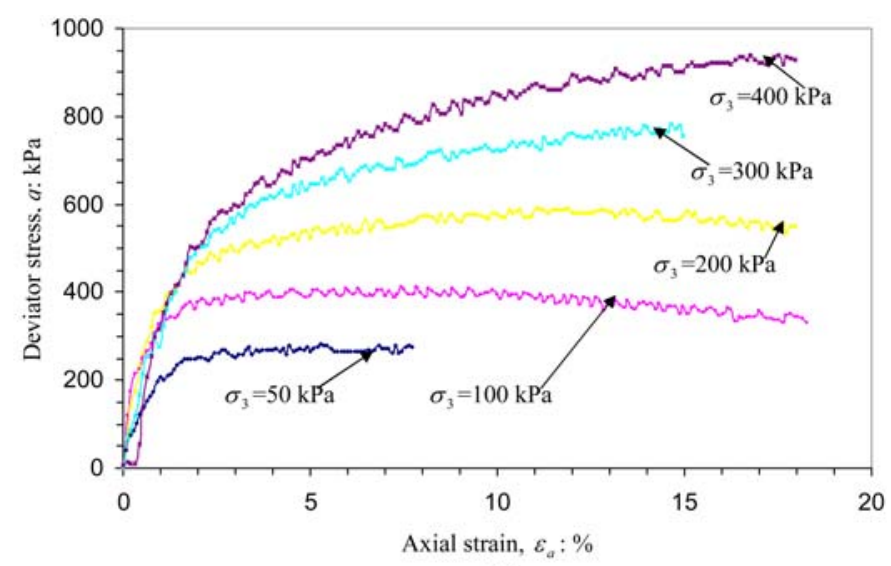

(a)

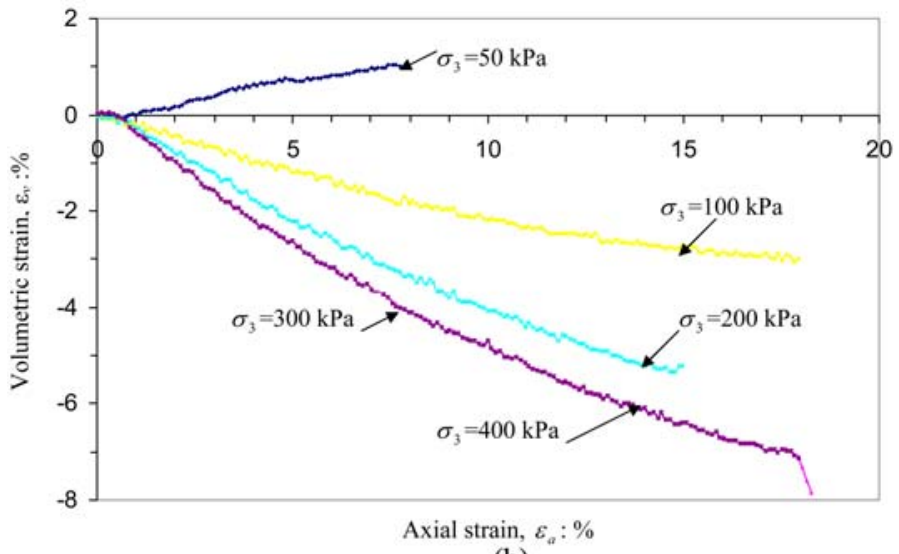

(b)

Fig. 4 (a) Stress-strain curves, (b) Volumetric strain-axial strain curves for samples tested at $s=100 \mathrm{kPa}$ under various cell pressures 


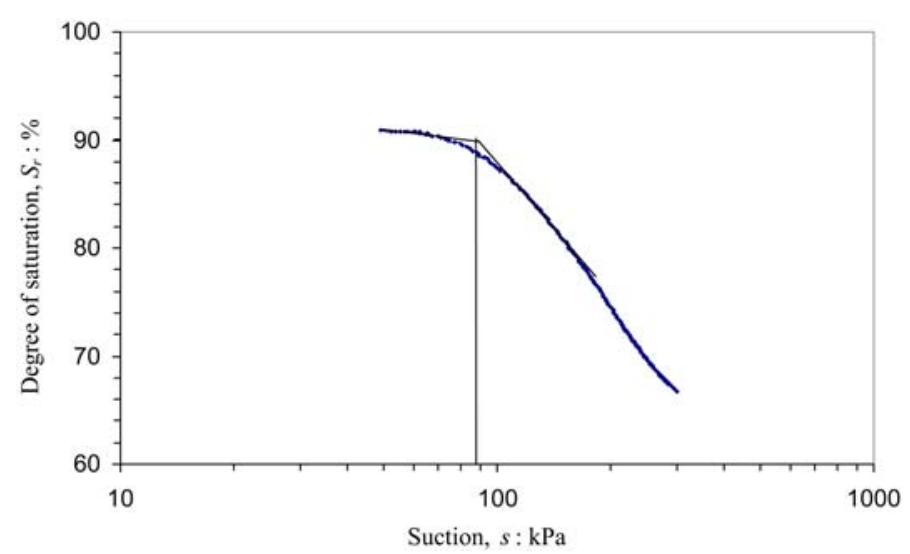

Fig. 5 Soil water characteristic curve

expressed using a negative sign, and a positive sign is used for dilation of the sample in the graphs of volumetric strain versus axial strain. Fig. 5 shows the soil water characteristic curve in the space of suction and degree of saturation. The initial of suction was $50 \mathrm{kPa}$ and it was increased gradually to the final value of $300 \mathrm{kPa}$.

\section{Discussion}

The NCLs (Normal Consolidation Lines) were found to be linear within the range of suction and net stress investigated in this work. The NCLs can be characterised using the conventional relationship

$$
v=N(s)-\lambda(s) \ln \frac{p^{n e t}}{p_{c}}
$$

Where $v$ and $p_{c}$ are specific volume and reference pressure respectively. $N(s)$ (intercept) is the value of specific volume at the reference pressure and $\lambda(s)$ is the compressibility parameter (slope of normal consolidation line) representing changes in specific volume with mean net stress on the virgin line. For the isotropic stress state, the intersection of the yield surface with $q=0$ plane defines a loading-collapse (LC) yield curve, with the isotropic yield stress increasing with increase in suction from the saturated value at zero suction. The stress states on the LC yield curve correspond to the normal conditions, and the resulting values of specific volume lie on a unique isotropic normal compression surface in $v-p^{\text {net }}$ space, which can be expressed by Eq. (3). This corresponds to a series of normal compression lines for different values of suction in the $v-p^{\text {net }}$ plane. The LC yield curve was produced from the yield points obtained from the isotropic consolidation curves as shown in Fig. 6. The shape of the LC yield curve is consistent with that proposed in the Alonso et al. (1990) model and is also in agreement with the results of researchers such as Wheeler and Sivakumar (1995) and Jotisankasa et al. (2009).

It was found from the experimental results that $\lambda(s)$ is a function of suction. The value of $\lambda(s)$ decreased with increasing suction (for suction greater than about $70 \mathrm{kPa}$ ) but $\lambda(s)$ appears to have decreased sharply as the suction reduced to zero. This behaviour is not consistent with model of 


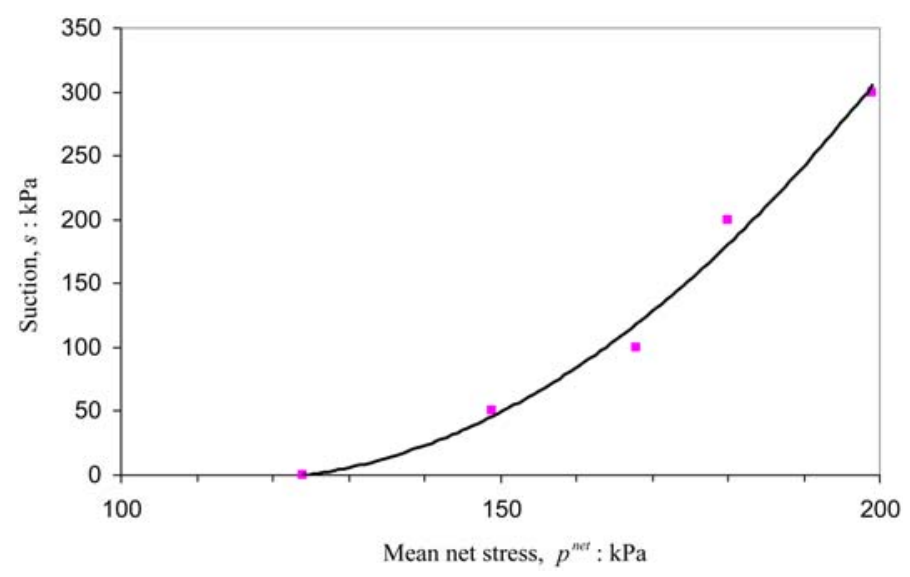

Fig. 6 Loading-collapse (LC) yield curve

Alonso et al. (1990) who proposed that the slope of isotropic normal consolidation line $\lambda(s)$ decreases monotonically with increasing suction from saturation condition. The results from Wheeler and Sivakumr (1995) showed a similar trend. This variation can not be fitted precisely with BBM expression for the variation of $\lambda(s)$ with suction. The results show that the value of $N(s)$ (intercept) in Eq. (3) also is function of suction. The variations of $N(s)$ with suction is similar to that of $\lambda(s)$. It increases with suction until the suction of about $70 \mathrm{kPa}$ and then decreases and its variations for suction greater than $200 \mathrm{kPa}$ is not noticeable. These findings are inconsistent with the results that were presented by Sivakumar (1993). He concluded from experimental tests on samples of kaolin that the values of $N(s)$ increase with increasing suction. This difference in results may be due to the different type of the soil that was used in this work.

The results of the triaxial test conducted at cell pressure of $50 \mathrm{kPa}(\mathrm{OCR}=11)$ (Fig. 4) show that the deviator stress increased to a peak value of $250 \mathrm{kPa}$ at about $2 \%$ axial strain and after that it became nearly constant. It is observed that during the shearing test the volume of the sample increased after a slight initial contraction. In the test with cell pressure of $100 \mathrm{kPa}(\mathrm{OCR}=5.5)$ shear test was conducted to an axial strain of about $18 \%$ as shown in Fig. 4. The deviator stress increased to a peak value of about $370 \mathrm{kPa}$ at axial strain of about $2 \%$ and then remained nearly constant. The volume of this sample decreased during shearing. The shear tests for cell pressures of 200,300 and $400 \mathrm{kPa}(\mathrm{OCR}=2.75,1.83$ and 1.37) were performed up to 18,15 and $18 \%$ axial strains respectively. In these tests the deviator stress increased to a peak value and then remained nearly constant. It is obvious that in the test with cell pressure of $50 \mathrm{kPa}$ and suctions of 200 and $300 \mathrm{kPa}$ the deviator stress first increased and then slightly decreased; during shearing the volume of these samples increased after a slight initial contraction. Therefore these samples with cell pressure of $50 \mathrm{kPa}$ exhibited a relatively brittle behaviour during shearing and a slight increase in total volume was observed after an initial compression. This behaviour can be attributed to the influence of suction on the stiffness, brittleness and dilatancy of the soil sample at low confining pressure (high OCR value), but with increasing suction the brittleness of soil sample increased especially at low confining pressures. Fig. 7 shows typical results of variation of maximum deviator stress with suction at constant cell pressure of $300 \mathrm{kPa}$. This figure shows that the deviator stress increased with increasing suction in a nonlinear fashion. The deviator stress increased linearly with suction until $s=100 \mathrm{kPa}$ and then increased nonlinearly until suction of about $200 \mathrm{kPa}$ after which 


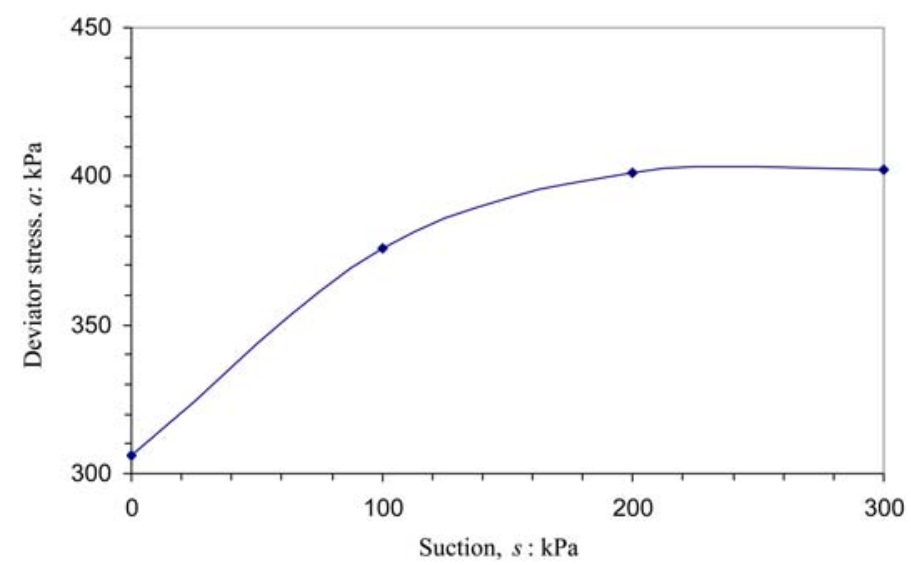

Fig. 7 Variations of maximum deviator stress with various suction at $\sigma_{3}=300 \mathrm{kPa}$

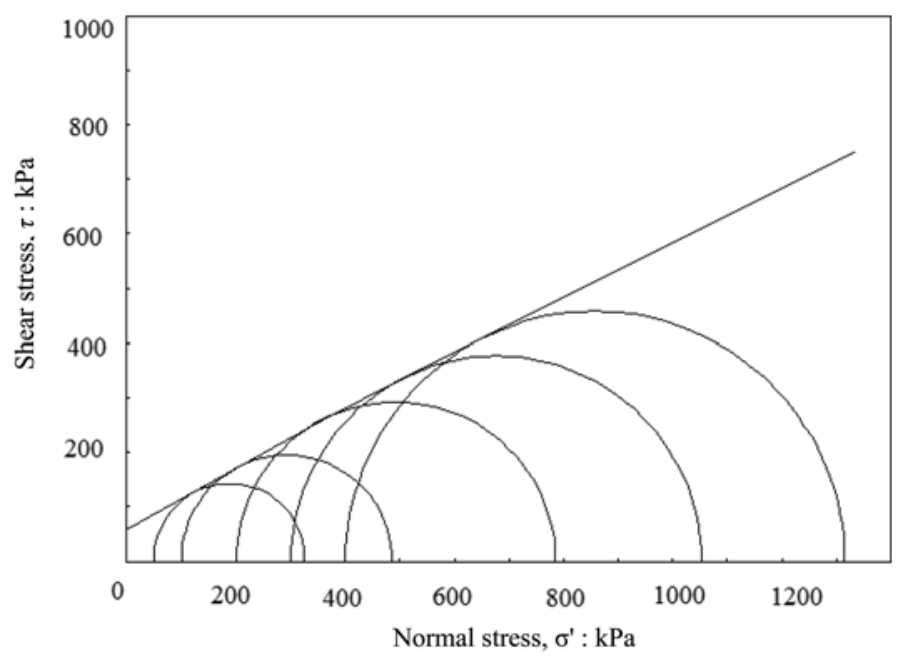

Fig. 8 Typical results of the envelope under suction of $100 \mathrm{kPa}$ and different confining stress

it remained almost constant. Although the brittleness of soil decreased with increasing confining pressure, but it can be concluded that the strength of soil sample increases with increasing suction in a nonlinear fashion. Under constant suction the increase in cell pressure causes a progressive evolution from dilatancy to compression behaviour until the dilatancy completely disappears. Typical failure envelope is presented in Fig. 8. Each of the Mohr-Coulomb failure envelopes was plotted based on Mohr circles from three triaxial tests at a constant matric suction. In plotting the failure envelopes it was assumed that the effective angle of internal friction, $\phi^{\prime}$ was constant. The cohesion intercepts of the failure envelopes on the zero confining stress $\left(\sigma_{3}-u_{a}\right)$ plane were joined together to give a failure envelope with respect to matric suction. Fig. 9 also presents another pattern of increase in cohesion intercept with increase in suction for all samples tested at different confining pressures (the value of $c^{\prime}$ was obtained from the failure envelope to Mohr circles). This figure shows that the variation of $c^{\prime}$ with suction is linear until suction of $100 \mathrm{kPa}$. It increases with increasing suction until $200 \mathrm{kPa}$ in a nonlinear fashion; and beyond $s=200 \mathrm{kPa}$ it is nearly 


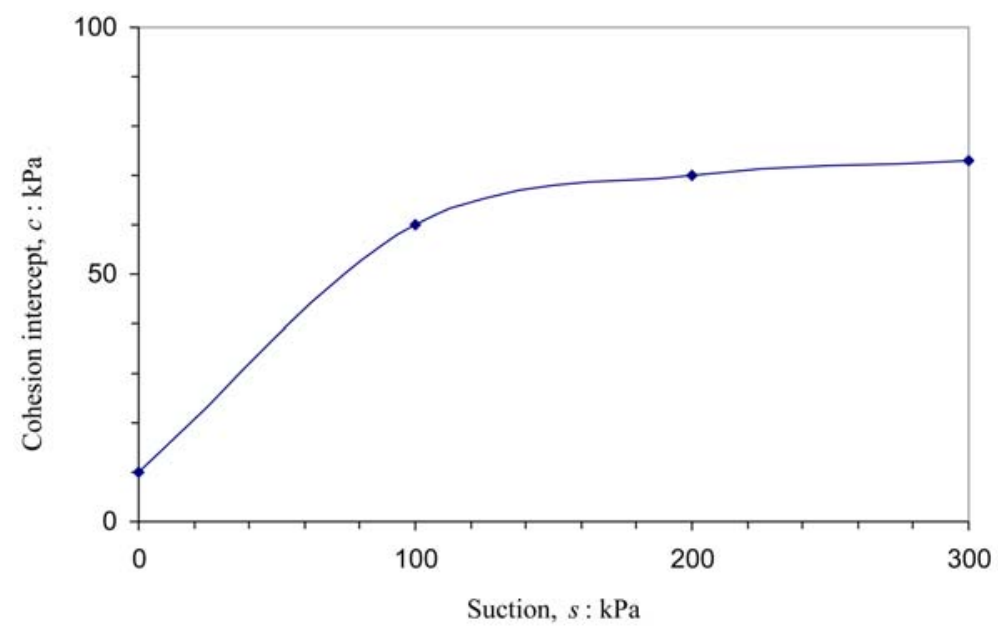

Fig. 9 Variations of $c$ with suction

constant. These findings are consistent with the results that were presented by Rahardjo et al. (2004). From a series of consolidated drained tests they found a nonlinear relationship between $c^{\prime}$ and suction but the value of $c^{\prime}$ increased with increasing suction. It is resulted from Figs. 7 and 9 that the deviator stress and cohesion increased until suction of $200 \mathrm{kPa}$ beyond which their variations were insignificant.

The air entry value of the soil was estimated as $85 \mathrm{kPa}$, (Fig. 5) based the method that was proposed by Vanapalli et al. (1999). It can be said that the of air entry value is a limit between the linear and non linear parts of maximum deviator stress-suction and effective cohesion-suction curves (Figs. 7 and 9). Therefore, the air entry value has a significant effect on the linear and nonlinear variation of strength. The suction of $200 \mathrm{kPa}$ appears to have an important role in the mechanical behaviour of this soil in that, beyond $s=200 \mathrm{kPa}$, further increase in suction does not have a significant effect on the behaviour of the soil. It is important to note that this suction $(200 \mathrm{kPa})$ is not the same as the air entry value of the soil.

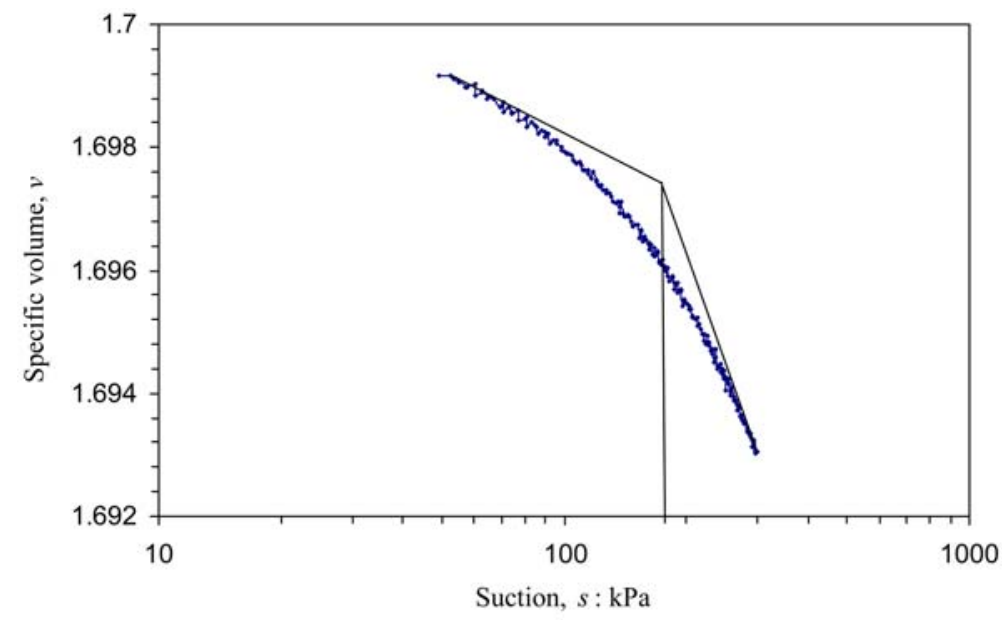

Fig. 10 Variations of specific volume with suction 
Fig. 10 shows the variations of specific volume with suction. The yield point was estimated from this figure to be about $190 \mathrm{kPa}$, using the method that was proposed by Cui and Delage (1996). Therefore, it can be said that the yield point due to increasing suction is an important point in changing the behaviour of unsaturated soils due to suction (Estabragh et al. 2000). Physically this can be explained by the following argument. As suction increases from zero, more water-filled voids become air-filled, leading to additional stability in particle contacts. However, once most of the voids become air-filled, additional stability at inter particle contacts primarily depends on suction. But additional forces reach a limiting value, meaning that any increase in shear strength after a certain value of suction would be insignificant. Some researchers such as Fredlund and Rahardjo (1993) and Vanapalli et al. (1999) concluded that there is a specific level or boundary beyond which, further increase in suction will not result in any significant change in mechanical behaviour of unsaturated soils.

\section{Conclusions}

Results from an experimental program consisting of a series of controlled suction consolidation and drained triaxial tests were used to investigate the effect of suction on subsequent mechanical behaviour of unsaturated silty soil. Based on the test results the following conclusions can be drawn:

(1) With increasing suction the yield stress increases but $\lambda(s)$ and $N(s)$ first increase until to a suction nearly equal to $70 \mathrm{kPa}$ then monotonically decrease.

(2) The LC yield curve is consistent with the model of Alonso et al. (1990).

(3) Dilatancy in the sample depends on the value of suction at a given confining pressure, higher suctions cause more dilatancy.

(4) The air entry value and yield point have important role in the behaviour of unsaturated soils. Yield point due to increasing suction can be considered as a boundary beyond which the effect of suction on strength of soil is insignificant.

\section{References}

Alonso, E.E., Gens, A. and Josa, A. (1987), "Special Proplems Soils, General Report", Proceedings of the 9th European Conference Soil Mechanics, Dublin, 1083-1146.

Alonso, E.E., Gens, A. and Josa, A. (1990), "A constitutive model for partially saturated soils", Géotechnique, 40(3), 405-430.

Bishop, A.W. (1959), "The Principal of effective Stress", Tek, Ukebled.

Bolzon, G., Schrefler, B.A. and Zienkiewicz, O.C. (1996), "Elastoplastic soil constitutive laws generalized to partially saturated states", Géotechnique, 46(2), 279-289.

Cui, Y.J. and Delage, P. (1996), "Yielding and plastic behaviour of an unsaturated compacted silt", Géotechnique, 46(2), 405-430.

Escario, V. and Saez, J. (1986), "The shear strength of partially saturated soils", Géotechnique, 36, 453-456.

Datcheva, M. and Schanz, T. (2003), "Anisotropic bounding surface plasticity with rotational hardening for unsaturated friction material”, Journal de Physique iv, 105, 305-312.

Estabragh, A.R., Javadi, A.A. and Boot, J.C. (2004), "Effect of compaction pressure on consolidation behaviour of unsaturated silty soil", Can. Geotech. J., 41(3), 540-550.

Estabragh, A.R., Javadi, A.A. and Boot, J.C. (2000), "An experimental study of elastic volume change in 
unsaturated soils", Proc. Asian Conference on Unsaturated Soils, Singapore, 651-655.

Fredlund, D.G. and Morgenstern, N.R. (1977), "Stress state variables for unsaturated soils", J. Geotech. Eng. ASCE, 103, 447-466.

Fredlund, D.G., Morgenstern, N.R. and Widger, R.A. (1978), "The shear strength of unsaturated soils", Can. Geotech. J., 15(3), 313-321.

Fredlund, D.G., Rahardjo, H. and Gan, K.M. (1987), "Non linearity of strength envelope for unsaturated soils", Proceedings of th $6^{\text {th }}$ International Conference on Expansive Soils, New Delhi, India, 1-4.

Fredlund, D.G. and H. Rahardjo, (1993), "Soil mechanics for unsaturated soils", John Wiley \& Sons: New York, USA.

Gallipoli, D., Gens, A., Sharma, R.S. and Vaunat, J. (2003), "An elasto-plastic model for unsaturated soil incorporating the effect of suction and degree of saturation on mechanical behaviour", Géotechnique, 53(1), 123-135.

Gan, J.K.M., Fredlund, D.G. and Rahardjo, H. (1988), "Determination of shear strength parameter for unsaturated soil using direct shear test", Can. Geotech. J., 25(3), 500-510.

Jenning, E.B. and J.B. Burland, (1962), "Limitation to the use of effective stress in partially saturated soils", Géotechnique, 2, 125-144.

Jotisankasa, A., M. Coop, M. and A. Ridley, (2009), "The mechanical behaviour of an unsaturated compacted silty clay", Géotechnique, 59, 415-428.

Karube, D. (1988), "New concept of effective stress in unsaturated soil and its proving test", Advanced Triaxial Testing of Soil And Rock, ASTM STP 977, 539-552.

Khalili, N., Habte, M. and Valliappan, S. (2005), "A bounding surface plasticity model for cyclic analysis of sands", Int. J. Numerical Methods in Engineering, 63(14), 1939-1960.

Khalili, N. and Khabbaz, M.H. (1998), "A unique relationship for $\chi$ for the determination of shear strength of unsaturated soils", Géotechnique, 48(5), 681-688.

Kohgo, Y., Nakano, M. and Miyazaki, T. (1993), "Verification of generalised elasto-plastic model for unsaturated silsm", Soil and Foundation, 33, 64-73.

Matyas, E.I. and Radhakrishna, H.S. (1968), "Volume change characteristics of partially saturated soils", Géotechnique, 18(4), 432-448.

Lu, N. and Likos, W.J. (2004), Unsaturated soil mechanics, John Wiley \& Sons, Inc, Hoboken, NJ, USA.

Lu, N. and Likos, W.J. (2006), "Suction stress characteristic curve for unsaturated soil", J. Geotech. Geoenviron. Eng., ASCE, 132(2), 131-142.

Rahardjo, H., O.B. Heng, O.B. and Choon, L.E. (2004), "Shear strength of a compacted residual soil from consolidate drained and constant water content triaxial tests", Can. Geotech. J., 41(3), 421-436.

Russel, A.R. and Khalili, N. (2006), "A unified bounding surface plasticity model for unsaturated soil", Int. J. Numer. Anal. Method. Geomech., 30(3), 181-212.

Sharma, R.S. (1998), "Mechanical behaviour of unsaturated highly expansive clays", $\mathrm{PhD}$, thesis, University of Oxford, Oxford, UK.

Sivakumar, V. (1993), "A critical state framework for unsaturated soils", PhD thesis, University of Sheffield, Sheffiel UK.

Wheeler, S.J. and Sivakumar, V. (1995), "An elasto plastic critical state framework for unsaturated soil", Géotechnique, 45(1), 35-53.

Wheeler, S.J., Sharma, R.S. and Buissen, M.S.R. (2003), "Coupling of hydraulic hystersis and stress-strain behaviour in unsaturated soils", Géotechnique, 53(1), 41-54.

Vanapalli, S.K., Pufahl, D.E. and Fredlund, D.G. (1999), "Interpretation of the shear strength of unsaturated soils in undrained loading conditions", Proc. 52nd Canadian Geotechnical Conference, Regina, Sask. Canada, 643650.

Yang, C., Cui, Y.J., Pereiro, J.M. and Huang, M.S. (2008), "A constitutive model for unsaturated cemented soils under cyclic loading”, Comput. Geotech., 35(6), 853-859. 